\title{
Redescription of the genus Diopsosoma Malloch (Diptera, Periscelididae)
}

\author{
Wayne N. Mathis ${ }^{1} \&$ Alessandra Rung ${ }^{1}$
}

\begin{abstract}
${ }^{1}$ Department of Entomology, NHB 169, PO BOX 37012, Smithsonian Institution, Washington, D.C. 20013-7012, United States. E-mail: mathis.wayne@nmnh.si.edu; baptist@wam.umd.edu
\end{abstract}

\begin{abstract}
Resumo. Redescrição do gênero Diopsosoma Malloch (Diptera, Periscelididae). Diopsosoma Malloch, 1932 e sua única espécie conhecida, D. primum Malloch, 1932 são redescritos. O gênero, embora facilmente reconhecível pela cabeça projetada lateralmente em pedúnculos oculares, é praticamente desconhecido. Por isso, apresenta-se sua redescrição em conjunto com breves redescrições de Periscelididae e da subfamília Periscelidinae. Chave para os gêneros de Periscelididae e fotomontagem do holótipo, talvez o único exemplar preservado da espécie, são fornecidas.
\end{abstract}

Palavras-Chave. Diopsosoma primum; Diptera; Neotropical; Periscelididae.

Abstract. Diopsosoma Malloch, 1932 and its only included species, D. primum Malloch, 1932 are redescribed. While the genus is remarkable and easily recognized by its laterally elongate head that is produced into eyestalks, it is otherwise virtually unknown. To bring attention to this extraordinary fly we redescribe it within the context of brief descriptions of the family Periscelididae and subfamily Periscelidinae. We also provide an annotated key to the described genera of Periscelididae and a photographic montage of the holotype, which is perhaps the only preserved specimen of this genus and species.

Keywords. Diopsosoma primum; Diptera; neotropics; Periscelididae.

The family Periscelididae presently comprises nine genera of which three, Marbenia Malloch, 1931, Diopsosoma Malloch, 1932, and Parascutops Mathis \& Papp, 1992, are monotypic. The three monotypic genera are known only from the New World tropics, and specimens are seldom collected. Although apparently rare in nature, we suspect that specimens will be found to be more common once the natural history of the species has been discovered. Malloch $(1931,1932)$ described two of the monotypic genera, Marbenia and Diopsosoma respectively, and the latter genus is the subject of this paper. We dedicate this paper to Dr. Hugo de Souza Lopes who inspired and encouraged us, was our friend and colleague, and whose professional career was dedicated to the discovery and description of little known or undescribed Neotropical Diptera.

Specimens of Diopsosoma are rare and compared to other Periscelididae are unusual because of their relatively large size. Specimens are most remarkable, however, because of their conspicuous and laterally elongate eyestalks, which are somewhat reminiscent of Old World species of the family Diopsidae. Although Diopsosoma is easily recognized by its remarkable and elongate eyestalks, the genus and its only included species, D. primum Malloch, 1932, are still known only from the type series. Malloch described Diopsosoma from a male holotype and two female paratypes. Of these three specimens, only the holotype is available to us. At least one of the paratypes has apparently been lost or destroyed, and the status of the second paratype remains undetermined. Malloch's colleague, R. C. Shannon, collected the type series in Iquitos, Peru (Departamento de Loreto), in April of 1931, and since then we are unaware of any additional specimens. Thus, this paper is based on the holotype only.

Malloch's generic description is brief, consisting of five published lines that are mostly a comparison with the family Diopsidae, which is not closely related, and a reference to the accompanying key, which outlines features that distinguish Diopsosoma from other genera of Periscelididae. Malloch's species description of $D$. primum is more detailed and he also published illustrations of the female head and the apex of the male and female abdomens. Other than Malloch's descriptions and illustrations, we know little else about the genus, and the general morphology has not been reviewed or re-evaluated since the genus and species were originally described, now over 70 years ago, despite major changes in the concept of the family Periscelididae and its included genera (MATHIS \& PAPP 1998).

Our purpose in this paper is to redescribe the genus and its only included species, D. primum, and to present photos of the holotype. We hope that this paper will encourage and facilitate the collection of additional specimens, their identification, and the further study of their natural history. To provide broader context for this paper and also to facilitate the identification of Diopsosoma and its included species, we have provided brief diagnoses for the family Periscelididae and subfamily Periscelidinae, and keys to the genera of Periscelididae.

\section{METHODS AND MATERIALS}

The descriptive terminology, with the exceptions noted in 
BAPTISTA \& MATHIS (1994), follows that published in the Manual of Nearctic Diptera (McAlpine 1981). Two venational ratios that are used in the descriptions are defined below. Costal vein ratio: the straight-line distance between the apices of $\mathrm{R}_{2+3}$ and $\mathrm{R}_{4+5}$ /distance between the apices of $\mathrm{R}_{1}$ and $\mathrm{R}_{2+3}$. $\mathrm{M}$ vein ratio: the straight-line distance along vein $\mathrm{M}$ between crossveins $\mathrm{dm}-\mathrm{cu}$ and $\mathrm{r}-\mathrm{m} /$ distance apicad of dm-cu.

The photographs were taken with an Auto-Montage Digital Imaging System ${ }^{\circledR}$, using a Wild Photomakroskop M400 ${ }^{\circledR}$ stereomicroscope. The photographs were enhanced, formatted, and arranged on plates in Adobe PhotoShop ${ }^{\circledR}$.

\section{Periscelididae Oldenberg, 1914}

Periscelidinae Oldenberg 1914: 41.

Periscelidae; Hendel 1916: 297.

Periscelididae; Stackelberg, 1933.

Diagnosis. Head. Frons with 1-2 fronto-orbital setae; postocellar setae divergent or absent. Pedicel cap-like and with a dorsal cleft, bearing 1 or more dorsoapical setae; $1^{\text {st }}$ flagellomere frequently sharply deflexed, arising from ventral surface of pedicel; arista pectinate. Face uniformly sclerotized and arched, setose laterally.

Thorax. Dorsocentral setae usually $2(0+2)$, sometimes 1 $(0+1)$, no presutural; posterior intra-alar seta reduced in size; scutellum with 1-2 pairs of marginal setae; scutellar disc bare; anepisternal seta usually lacking (present in Planinasus). Wing: subcosta rudimentary, not reaching costal margin, but not fused apically with $R_{1}$; no costal breaks (a weakness in the costal just apicad of the humeral crossvein in Planinasus); costa extended to $\mathrm{R}_{4+5}$ or $\mathrm{M}$; cell $\mathrm{dm}$ with a fold running entire length; cell cup usually present with vein $\mathrm{CuA}_{2}$ either well developed or extremely reduced. Midtibia bearing a prominent, apicoventral seta.

Discussion. According to McAlpine (1989), the family Periscelididae is in the suprafamily Asteioinea (superfamily Opomyzoidea). All families of Asteioinea (McAlpine 1989) have a well-sclerotized, often bulbous face (secondarily reduced in some Asteiidae and Xenasteiidae), which is a possible synapomorphy for the suprafamily.

The concept of Periscelididae adopted here follows McAlpine $(1978,1983)$ and includes a few genera previously assigned to Aulacigastridae (Cyamops Melander, Planinasus Cresson, and Stenomicra Coquillett). Whether Somatia also belongs here, as advocated by GRIFFITHS (1972), requires further study. Structures of the male terminalia of Somatia are very similar to those of Psilidae, and we agree with McAlpine (1989) that this genus is probably closely related to Psilidae.

No synapomorphies have been proposed for the Periscelididae that do not also occur in closely related families. McAlpine characterized Periscelididae primarily by the caplike pedicel, which has a dorsal cleft. Although this character is common to all Periscelididae, it also occurs in the family Neurochaetidae (MCALPINE 1978; WoodLey 1982) and other, more distantly related families. Periscelididae have a well- developed greater ampulla (MCALPINE 1989), but this character is also present in Aulacigastridae.

Key to Subfamilies of Periscelididae

1. Fronto-orbital seta 1; ocellar setae present. Costa short, extended to vein $\mathrm{R}_{4+5} ; \mathrm{CuA}_{2}$ weak or lacking, lacking a cell cup; postpronotum bearing a well-developed seta Periscelidinae

Fronto-orbital setae 2; ocellar setae absent. Costa long, extended to vein $\mathrm{M} ; \mathrm{CuA}_{2}$ usually well developed, usually with a distinct cell cup (weak or lacking in Stenomicra); postpronotum lacking a well-developed seta Stenomicrinae

\section{Periscelidinae Oldenberg, 1914}

Periscelidinae Oldenberg 1914: 41.

Diagnosis. Head. Eye microsetulose; occiput with a silvery white, microtomentose area immediately adjacent to posterior margin of compound eye; frons with 1 fronto-orbital seta only, reclinate; postocellar setae present, divergent; ocellar setae present, well developed; face uniformly sclerotized and transversely arched (shield-like in Scutops); face setose laterally, strongly receded ventrally, extended laterally below gena; gena extended anterodorsally, bearing a row of setae, with anterior one inserted well above oral margin; mouth opening large.

Thorax. Postpronotal seta well developed. Wing with costa short, extended only to $\mathrm{R}_{4+5}$; cell cup either lacking or present but very weakly developed and with vein $\mathrm{CuA}_{2}$ extremely reduced resulting in cell cup being mostly to completely open. Mibtibia bearing an apical ventral spine-like seta; tibiae often with subapical and sub-basal, dark colored annulus (secondarily lost or covered over in some species).

Abdomen: 7th spiracle ("stigma") not free in female postabdomen. See Griffiths (1972) for discussion of male terminalia.

Natural history. We only know the immature stages of the genus Periscelis, which are associated with sap from bleeding deciduous trees (oak, elm, and cottonwood). TESKey (1976) described and figured a larva of Periscelis sp. Adults of Periscelis are also usually found in association with trees with bleeding wounds.

Discussion. The genera comprising Periscelidinae are those that HeNNIG (1969) included in his more restricted concept of the family, viz: Periscelis Loew, Marbenia Malloch, Neoscutops Malloch, Parascutops Mathis \& Papp, Scutops Coquillett, and Diopsosoma Malloch. These six genera comprise a well-established monophyletic assemblage, with corroborating synapomorphies as follows: 1) mouth opening large (this may be secondarily reduced in Diopsosoma, although this is difficult to determine, given the severe lateral 


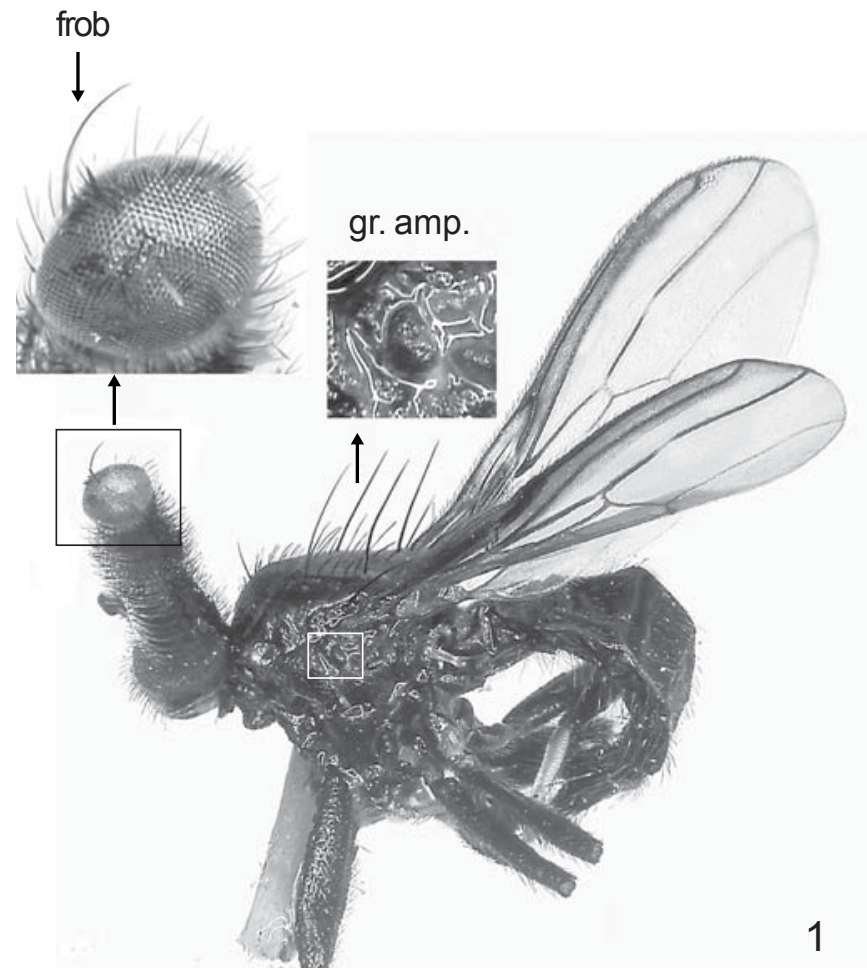

Fig. 1. Habitus of Diopsosoma primum (Holotype male; Peru. Loreto: Iquitos) with details of compound eye and lateroreclinate fronto-orbital seta and greater ampulla, lateral.

distentions of the head); 2) occiput with a silvery white, microtomentose area immediately adjacent to the posterior margin of the compound eye (this character is difficult to assess in Diopsosoma because of the laterally distended head into eyestalks); 3) only one fronto-orbital seta, reclinate (lateroreclinate in Diopsosoma); 4) costal vein short, extended only to vein $\mathrm{R}_{4+5}$. The plesiomorphic condition, found in related genera and families, is for the costal vein to extend to vein $\mathrm{M}$; 5) vein $\mathrm{CuA}_{2}$ reduced or absent. Plesiomorphically this vein is present, resulting in a well-defined cell cup. Its reduction or absence here is an autapomorphy; 6) several characters of the male terminalia (see GrifFITHS 1972).

\section{Key to genera of Periscelidinae}

1. Eyes borne on conspicuous eyestalks. Presutural seta well developed; anepisternum setulose; scutellar apex bearing patch of long setulae between apical scutellar setulae. Diopsosoma Malloch [Type species: Diopsosoma primum Malloch; Neotropical (Peru)]

Eyes not borne on conspicuous stalks. Lacking a presutural seta; anepisternum bare of setulae; scutellar apex lacking apical patch of setae

2(1). Vein $R_{1}$ bearing numerous setulae along dorsum .......... 3 Vein $\mathrm{R}_{1}$ lacking setulae along dorsum
3(2). Vein $\mathrm{R}_{2+3}$ curved anteriorly toward costa to just beyond $\mathrm{R}_{1}$, thereafter reverse curved more or less evenly, shallowly, and parallel to costa until merger with latter; apical section of vein M usually conspicuously arched; 1 posterior dorsocentral seta

Neoscutops Malloch

[Type species: Neoscutops rotundipennis Malloch; Neotropical (Brazil, Colombia, Costa Rica, Guyana, Peru, Venezuela)]

Vein $\mathrm{R}_{2+3}$ more or less evenly arched throughout length except just before apex; apical section of vein $\mathrm{M}$ straight or very shallowly arched; 2 posterior dorsocentral setae .................. Marbenia Malloch [Type species: Marbenia pecularis Malloch; Neotropical (Costa Rica, Peru)]

4(2). Dorsal area of face distinctly flattened, shieldlike. Wing with at least apical $1 / 3$ conspicuously infuscate ..... 5

Dorsal area of face not distinctly flattened and shieldlike. Wing variable but usually mostly hyaline

Periscelis Loew

[Type species: Periscelis annulipes Loew; Nearctic, Neotropical, Palearctic]

5(4). Wing irrorate; mesonotum densely microtomentose, appearing dull, mostly gray with several brown spots; a pair of distinct prescutellar acrostichal setae. Arista with 3-4 dorsal branches

Parascutops Mathis \& Papp

[Type species: Scutops maculipennis Malloch; Neotropical (Mexico)]

Wing darkly infumate on apical $1 / 2-1 / 3$ and with subapical, transverse, white area or band; mesonotum very thinly to moderately microtomentose, subshiny to shiny; prescutellar acrostichal setae lacking. Arista with 6 or more dorsal branches ...... Scutops Coquillett [Type species: Scutops fascipennis Coquillett; Neotropical (Belize south to Peru)

\section{Diopsosoma Malloch, 1932}

Diopsosoma Malloch, 1932: 267; Pires do Prado, 1975: 1 (Neotropical catalog).

Type species: Diopsosoma prima Malloch, 1932 by original designation.

Diagnosis. Adult body generally dark colored; head very elongate laterally with eyes borne on elongate eyestalks.

Head. Frons and face highly modified, both greatly distended laterally, forming elongate, symmetrical, somewhat robust, generally uniformly setulose, eyestalks (Fig. 2); ocellar setae proclinate, divergent; postocellar setae divergent, well developed, length almost twice that of ocellar setae; inner and outer vertical setae well developed but distant from each other, inner vertical seta at basal $1 / 3$ of stalk and outer vertical seta at apical 1/3 of eyestalk; 1 lateroreclinate, fronto-orbital seta at apex of eyestalk, seta extended partially over eye. Antennal bases distant, gap between subequal to antennal length; 


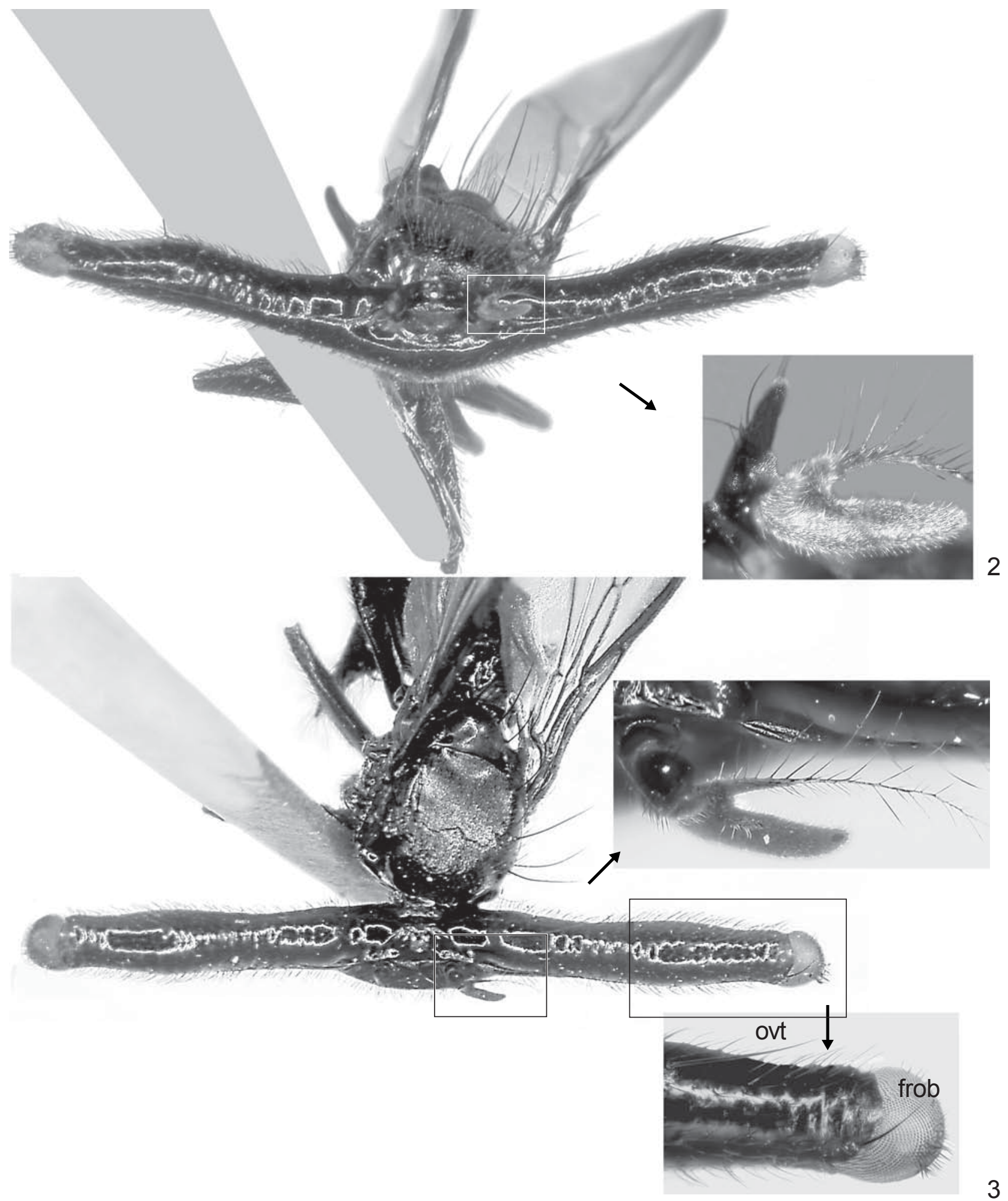

Figs. 2-3. Head of Diopsosoma primum (Holotype male; Peru. Loreto: Iquitos). 2, head and thorax with details of left antenna, anterior; 3, ibidem with details of left antenna, apex of the eyestalk, compound eye, and lateroreclinate fronto-orbital seta, dorsal.

pedicel narrowly and vertically triangular with dorsally rounded, apical point, bearing a subapical long setulae with dorsal orientation; flagellomere unequally bilobed at base, dorsal lobe much shorter, bearing arista at apex; ventral lobe much larger, digitiform, slightly tapered on apical half; arista pectinate, bearing numerous, hair-like, mostly dorsal branches in 2 rows. Face bearing numerous, short setulae; oral opening small, width about equal to distance between antennal bases; 

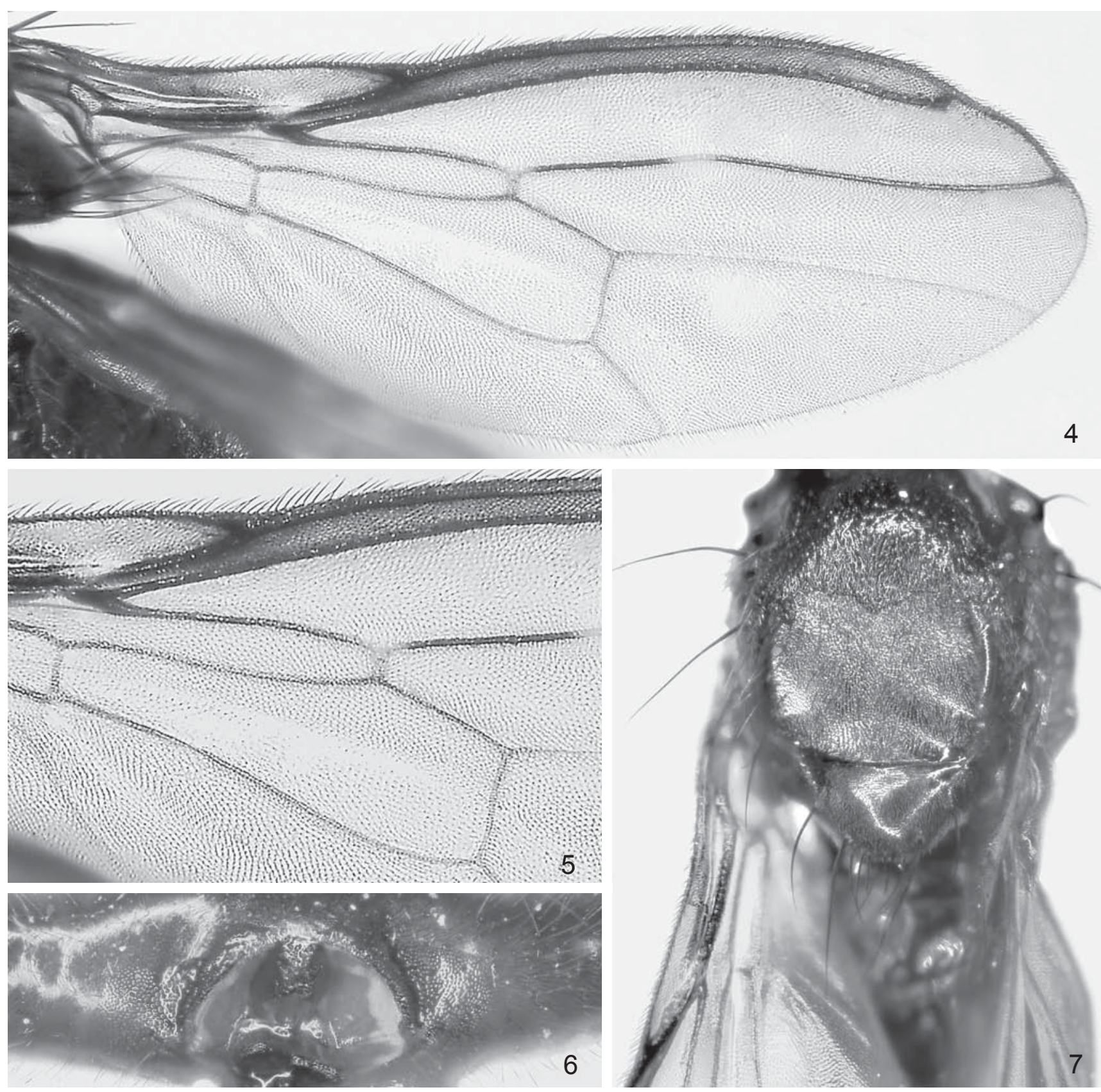

Figs. 4-7. Photographs of Diopsosoma primum (Holotype male; Peru. Loreto: Iquitos). 4, right wing, dorsal; 5, cells bm and dm, dorsal; 6, mouth opening, ventral; 7, mesonotum, dorsal.

clypeus narrow, width less length; palpus short, wide, flat, bearing setulae. Eyes borne on conspicuous, very laterally elongate eyestalks; eye bearing rows of long, black, interfacetal setulae.

Thorax. Chaetotaxy: 2 dorsocentral setae $(0+2) ; 1$ presutural and 1 postsutural supra-alar seta; 1 postalar seta; 2 scutellar setae and several long setulae between apical pair; 1 short postpronotal seta, subequal to half length of notopleural seta; 1 notopleural seta; anepisternum setose; scutellum triangular, apex pointed and bearing apical patch of setae; prescutellar acrostichal setae lacking; katepisternum bearing 1 slender seta. A well-developed greater ampulla. Wing with subcosta incomplete; vein $\mathrm{R}_{1}$ lacking setulae along dorsum; vein $\mathrm{R}_{2+3}$ more or less evenly and shallowly arched throughout length except just before apex; apical section of vein M nearly straight; cell dm with a medial fold along entire length, crossvein bm-cu well developed; closed cell cup absent; vein $\mathrm{CuA}_{2}$ absent.

Abdomen. Tergites black and moderately microtomentose except for apical tergite; tergites in dorsal view mostly parallel sided and with distinct dorsolateral crease; apical tergite (7th) 
essentially bare of microtomentum, narrow, and sharply pointed posteriorly.

Discussion. The only included species, D. primum, has eyestalks similar to Old-World Diopsidae, but otherwise this species is dissimilar from that family and is unrelated phylogenetically. The family Diopsidae, for example, is the nominate family of the superfamily Diopsoidea, and Periscelididae are in the superfamily Opomyzoidea, suprafamily Asteioinea (McAlpine 1989). Diopsosoma shares a wellsclerotized, bulbous face with other families of the suprafamily Asteioinea.

Malloch (1932) correctly recognized that Diopsosoma is in the family Periscelididae, and here we confirm its inclusion in the subfamily Periscelidinae despite the earlier doubts of GRIMALDI \& MATHIS (1993). Some characters of the head, which are synapomorphies for the subfamily Periscelidinae, are difficult to assess in Diopsosoma because of the laterally distended head. Like other genera in Periscelidinae, for example, there is a single fronto-orbital seta in Diopsosoma, but this seta is lateroreclinate rather than reclinate as in other Periscelidinae. Presumably the slightly altered orientation of this seta accompanied other modifications of the head with the lateral distensions to form the eyestalks. Diopsosoma also shares with other Periscelidinae a cap-like pedicel, a welldeveloped greater ampulla, a short costal vein, and the absence of a closed cell cup.

Although uncommon, hypercephaly occurs in eight families of Diptera and has apparently arisen at least 21 times (Grimaldi \& Fenster 1989). Like most Diopsidae, there is no pronounced sexual dimorphism in Diopsosoma primum, and we suggest, like Burkhardt \& De La Motte (1987) did for Diopsidae, that the eyestalks may enhance these flies' ability to "size up" opponents and potential mates, especially at greater distances than is possible for normal-headed flies. Although the "size-up" hypothesis is intuitively reasonable, it remains to be demonstrated in Diopsosoma.

\section{Diopsosoma primum Malloch, 1932}

$$
\text { (Figs. 1-7) }
$$

Diopsosoma prima Malloch, 1932: 267; Pires do Prado, 1975: 1 (Neotropical catalog).

Diagnosis. A large species of Periscelididae, wing length $7.70 \mathrm{~mm}$; body generally brownish black to black.

Head. Head chestnut brown dorsally between ocellar triangle and inner vertical seta, becoming darker laterally to black apex just before compound eye; venter of head chestnut brown just laterad of oral opening, thereafter laterally becoming more brownish black to black; head very laterally elongate (Figs. 1-3), width of male head (from eye apex to eye apex) $10.25 \mathrm{~mm}$; eyestalk generally bearing numerous, black setulae except for bare, dorsomedial area along eyestalk between inner vertical setae. Ocelli forming an equilateral triangle; a dense patch of long, white macropubescence immediately posterior of postocellar setae. Arista (Figs. 1-2) pectinate, bearing at least 25 hair-like branches in 2 mostly dorsal rows. Face around antennal bases yellowish. Eye (Figs. 1-3) bearing numerous, long, black, conspicuous, interfacetal setulae along apical margin in 2 more or less horizontal rows, more basal portions of eye bare of setulae.

Thorax (Figs. 1, 3, 7). Mesonotal length $3.80 \mathrm{~mm}$; mesonotum brownish black to black with moderate investment of light colored microtomentum and generally and uniformly with long, black setulae in addition to major setae except scutellar disc bare of setulae; scutellum (Fig. 7) slightly arched dorsally, posterior margin generally broadly rounded in dorsal view but slightly flattened between apical scutellar setae; apical scutellar seta longer than subapical seta; scutellum bearing a patch of 9-10 long, apical setulae between apical scutellar setae, length of setulae only slightly shorter than subapical scutellar seta; pleural area brownish black to black. Wing (Fig. 4) length $7.70 \mathrm{~mm}$; width $3.40 \mathrm{~mm}$; costal vein ratio 0.25 ; M vein ratio 0.26 ; wing mostly hyaline except for infuscate anterior margin, especially subcostal cell and cell $\mathrm{R}_{1}$, and some white spots; small white spots over anterior half of crossvein $\mathrm{r}-\mathrm{m}$ and immediate area, on vein $\mathrm{R}_{4+5}$ just beyond crossvein $\mathrm{r}-\mathrm{m}$, and in cell $\mathrm{M}$ just apicad of crossvein dm-cu and abutting vein $\mathrm{M}$; vein $M$ from crossvein $r-m$ to apex distinctly angulate; crossvein $\mathrm{dm}$-cu subequal to length of vein $\mathrm{M}$ between crossveins $\mathrm{r}-\mathrm{m}$ and dm-cu (Figs. 4-5). Knob of halter black, stem yellowish. Femora and tibiae generally black and relatively densely and uniformly setulose; basal 3 tarsomeres yellow; apical tarsomeres brownish black to black; midtibia bearing an apical seta ventrally.

Abdomen. Abdomen black, generally setulose; apical half curved anteroventrally (Fig. 1), total length greater than combined length of head and thorax; tergites in dorsal view somewhat parallel sided, with distinctive dorsolateral crease; tergites 1-5 more or less rectangular in dorsal view, wider than long; $6^{\text {th }}$ tergite trapezoidal; $7^{\text {th }}$ tergite narrow, 3 times longer than wide, tapered to a point, polished with sparse to no microtomentum, bearing numerous setulae.

Type material. The holotype male is labeled "Iquitos Peru Apr. 1931 R. C. Shannon [handwritten]/Diopsosoma prima Type det. JRMALLOCH [species name and "Type" handwritten]/Type No. 43865 U.S.N.M [red; number handwritten]." The holotype is double mounted (glued to a paper triangle), is in fair condition (wings partially torn, glue over much of thorax, giving it a "wet" appearance), and is deposited in the USNM (43865). A female paratype is apparently in the BMNH. The other female paratype has apparently been lost.

Distribution. Neotropical: Peru (Loreto).

Remarks. Although we have not examined a female of this species, MALLOCH (1932: 267) published an illustration of the female head and wrote that the female has laterally distended eyestalks like the male but that the head was not quite as wide.

Acknowledgments. We gratefully acknowledge the assistance and cooperation of many individuals who contributed to the production of this paper. Hollis B. Williams provided technical support. We also thank Irina Brake for reviewing a draft of this paper. 


\section{REFERENCES}

Baptista, A. R. \& W. N. Mathis. 1994. A revision of New World Cyamops Melander (Diptera, Periscelididae). Smithsonian Contributions to Zoology 563: 1-28.

Burkhardt, D. \& I. De la Motte. 1987. Physiological, behavioural, and morphometric data lucidate the evolutive significance of stalked eye in Diopsidae (Diptera). Entomologia Generalis 12: 221233.

Griffiths, G. C. D. 1972. The phylogenetic classification of Diptera Cyclorrhapha, with special references to the structure of the male postabdomen. Series Entomologica 8: 340 p. W. Junk, N.V., The Hague.

Grimaldi, D. A. \& G. Fenster. 1989. Evolution of extreme sexual dimorphisms: structural and behavioral convergence among broadheaded male Drosophilidae (Diptera). American Museum Novitates 2939: 1-25.

Grimaldi, D. A. \& W. N. Mathis. 1993. Fossil Periscelididae (Diptera). Proceedings of the Entomological Society of Washington 95(3): 383-403.

Hendel, F. 1916. Beiträge zur Systematik der Acalyptraten Musciden (Dipt.). Entomologische Mitteilungen 5(9/12): 294-299.

Hennig, W. 1969. Neue Gattungen und Arten der Acalyptratae. Canadian Entomologist 101(6): 589-633.

Malloch, J. R. 1931. Notes on some acalyptrate flies in the United States National Museum. Proceedings of the United States National Museum 78(15): 1-32.

Malloch, J. R. 1932. A new genus of diopsid like Diptera (Periscelidae). Stylops I(12): 266-268.

Mathis, W. N. \& L. PApP. 1992. A new genus of Periscelididae (Diptera) from the neotropics. Proceedings of the Biological Society of Washington 105(2): 366-372.

Mathis, W. N. \& L. PApp. 1998. 3.24. Family Periscelididae, p. $285-$
294. In: L. PAPP \& B. Darvas (Edits.). Contributions to a Manual of Palaearctic Diptera (with special reference to flies of economic importance). Vol. 3, Higher Brachycera. Budapest, Science Harold, $880 \mathrm{p}$

McAlpine, D. K. 1978. Description and biology of a new genus of flies related to Anthoclusia and representing a new family (Diptera, Schizophora, Neurochaetidae). Annals of the Natal Museum 23(2): 273-295.

McAlpine, D. K. 1983. A New Subfamily of Aulacigastridae (Diptera: Schizophora), with a Discussion of Aulacigastrid Classification. Australian Journal of Zoology 31: 55-78.

McAlpine, J. F. 1981. Morphology and terminology - adults, p. 9-63. In: J. F. McAlpine (Edit.). Manual of Nearctic Diptera. Volume 1. Monograph 27, Research Branch Agriculture Canada, Ottawa, $\mathrm{vi}+674 \mathrm{p}$.

McAlpine, J. F. 1989. Phylogeny and classification of the Muscomorpha, pp. 1397-1518. In: J. F. McAlpine (Edit.). Manual of Nearctic Diptera. Volume 3. Monograph 32, Research Branch Agriculture Canada, Ottawa, vi+ pp. 1333-1581.

Oldenberg, L. 1914. Beitrag zur Kenntnis der europäischen Drosophiliden (Dipt.). Archiv für Naturgeschichte 80A(2): 1-42.

Pires do Prado, A. 1975. 67. Family Periscelididae, p. 1-3. In: N. Papavero (Edit.). A catalogue of the Diptera of the Americas South of the United States. São Paulo, Departamento de Zoologia, Secretaria da Agricultura.

Stackelberg, A. A. 1933. Les mouches de la partie europeénne de 1'URSS. Tableaux Analytiques de la Faune de 1'URSS. Leningrad, Akademiia Nauk, 742 p.

Teskey, H. J. 1976. Diptera larvae associated with trees in North America. Memoirs of the Entomological Society of Canada 100: 1-53. Woodley, N. E. 1982. Two new species of Neurochaeta McAlpine (Diptera: Neurochaetidae), with notes on cladistic relationships within the genus. Memoirs of the Entomological Society of Washington 10: 211-218. 